\title{
Quality of metagenomic DNA extracted for molecular identification of microorganisms from CSF samples of patients with suspected cerebrospinal meningitis in northern Nigeria
}

\author{
*1,3Peletiri, I. C., ${ }^{1}$ Ikeh, E. I., ${ }^{2}$ Nna, E., ${ }^{3}$ Ndike, U. P., ${ }^{4}$ Usman, Y. B., ${ }^{5}$ Durfa, L. D., \\ ${ }^{6}$ Okonkwo, C. N., ${ }^{7}$ Murtala, R., and ${ }^{2}$ Nnajide, C. R. \\ ${ }^{1}$ Department of Medical Microbiology, Faculty of Clinical Sciences, College of Health Sciences, \\ University of Jos, Nigeria \\ ${ }^{2}$ Safety Molecular Pathology Laboratory, The Molecular Pathology Institute, Enugu, Enugu State, Nigeria \\ ${ }^{3}$ Medical Microbiology \& Parasitology Laboratories, National Hospital, Abuja, Nigeria \\ ${ }^{4}$ Public Health Laboratory, Ministry of Health, Kebbi, Kebbi State, Nigeria \\ ${ }^{5}$ Microbiology Laboratory, Plateau State Specialist Hospital, Jos, Nigeria \\ ${ }^{6}$ Medical Laboratory Department, Specialist Hospital, Sokoto, Sokoto State, Nigeria \\ ${ }^{7}$ Medical Laboratory Services, Ahmad Sani Yariman Specialist Hospital, Gusau, Zamfara State, Nigeria \\ *Correspondence to: kumochris@hotmail.com
}

\begin{abstract}
:
Background: Following an increase in the practice of starting antimicrobial therapy prior to clinical sample collection, the ability to confirm pathogenic microorganisms of bacterial meningitis has decreased by approximately $30 \%$. Culture results may be false negative when fastidious or culture-resistant bacteria are involved or when patient samples are obtained after antimicrobial therapy has started. Molecular diagnosis using PCR can be performed directly on clinical samples after metagenomic DNA (mDNA) extraction not requiring live organisms for a positive result. The specific objectives of this study are to perform mDNA extraction directly from cerebrospinal fluids (CSF) using appropriate spin column method, and to determine the quality of the mDNA elute.

Methodology: Cerebrospinal fluid specimens were collected from 210 patients with suspected acute cerebrospinal meningitis (CSM) in the Federal Capital Territory and some States in Northern Nigeria during the 2017 and 2018 outbreak seasons. Metagenomic DNA was extracted from approximately $200 \mu \mathrm{L}$ of CSF specimens using the Qiagen QIAamp $^{(R)}$ DNA Mini kit specific for bacterial agents only. DNA quality check was performed on all DNA elutes using fluorometric, spectrophotometric and agarose gel electrophoresis methods.

Results: Of the 210 CSF samples analyzed microbiologically, Gram reaction was positive in 94 cases (44.8 \%) but only $17(8.1 \%)$ were culture positive for two of the three major bacterial causes of meningitis. One hundred and

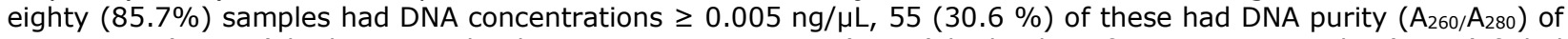
$\geq 1.7,103(57.2 \%)$ had purity value between $1.0-1.69,14(7.8 \%)$ had value of $0.57-0.99$, and $8(4.4 \%)$ failed purity evaluation with value of 0.00 at $A_{260 /} A_{280}$.

Conclusion: The essence of mDNA extraction is multipurpose. A multiplex PCR can be performed on the extracted mDNA to interrogate the presence of microbial pathogens of interest using specific primers and probes (when applicable). Quality mDNA from CSF samples will ensure successful qPCR results for rapid and accurate detection of bacterial pathogens in meningitis. This will eliminate the challenges associated with traditional culture methods.
\end{abstract}

Keywords: Meningitis, CSF, DNA Quality Check, Fluorometry.

Received Jun 5, 2020; Revised Oct 8, 2020; Accepted Nov 4, 2020

Copyright 2021 AJCEM Open Access. This article is licensed and distributed under the terms of the Creative Commons Attrition 4.0 International License <a rel="license" href="http://creativecommons.org/licenses/by/4.0/", which permits unrestricted use, distribution and reproduction in any medium, provided credit is given to the original author(s) and the source. Editor-in-Chief: Prof. S. S. Taiwo

\section{Qualité de I'ADN métagénomique extrait pour l'identification moléculaire des microorganismes à partir d'échantillons de LCR de patients suspectés de méningite cérébrospinale dans le nord du Nigéria}

\author{
*1,3Peletiri, I. C., ${ }^{1}$ Ikeh, E. I., ${ }^{2}$ Nna, E., ${ }^{3}$ Ndike, U. P., ${ }^{4}$ Usman, Y. B., ${ }^{5}$ Durfa, L. D., \\ ${ }^{6}$ Okonkwo, C. N., ${ }^{7}$ Murtala, R., et ${ }^{2}$ Nnajide, C. R.
}


${ }^{1}$ Département de microbiologie médicale, Faculté des sciences cliniques, Collège des sciences de la santé, Université de Jos, Nigéria

${ }^{2}$ Laboratoire de pathologie moléculaire de sécurité, Institut de pathologie moléculaire, Enugu, État d'Enugu, Nigéria

${ }^{3}$ Laboratoires de microbiologie médicale et de parasitologie, Hôpital national, Abuja, Nigéria

${ }^{4}$ Laboratoire de santé publique, ministère de la Santé, Kebbi, État de Kebbi, Nigéria

${ }^{5}$ Laboratoire de microbiologie, hôpital spécialisé du Plateau State, Jos, Nigéria

${ }^{6}$ Département de laboratoire médical, hôpital spécialisé, Sokoto, État de Sokoto, Nigéria

${ }^{7}$ Services de laboratoire médical, hôpital spécialisé Ahmad Sani Yariman, Gusau, État de Zamfara, Nigéria *Correspondance à: kumochris@hotmail.com

\section{Abstrait:}

Contexte: Suite à une augmentation de la pratique de commencer un traitement antimicrobien avant le prélèvement d'échantillons cliniques, la capacité à confirmer les microorganismes pathogènes de la méningite bactérienne a diminué d'environ $30 \%$. Les résultats de la culture peuvent être faux négatifs lorsque des bactéries exigeantes ou résistantes à la culture sont impliquées ou lorsque des échantillons de patients sont prélevés après le début du traitement antimicrobien. Le diagnostic moléculaire par PCR peut être réalisé directement sur des échantillons cliniques après extraction d'ADN métagénomique (ADNm) ne nécessitant pas d'organismes vivants pour un résultat positif. Les objectifs spécifiques de cette étude sont d'effectuer l'extraction de l'ADNm directement à partir des fluides céphalo-rachidiens (LCR) en utilisant la méthode de colonne de rotation appropriée, et de déterminer la qualité de l'élution d'ADNm.

Méthodologie: Des échantillons de liquide céphalo-rachidien ont été collectés auprès de 210 patients suspectés de méningite cérébrospinale aiguë (MSC) dans le Territoire de la capitale fédérale et dans certains États du nord du Nigéria au cours des saisons d'épidémie 2017 et 2018. L'ADN métagénomique a été extrait d'environ $200 \mu \mathrm{L}$ d'échantillons de LCR en utilisant le kit Qiagen QIAamp ${ }^{(R)}$ DNA Mini spécifique pour les agents bactériens uniquement. Un contrôle de la qualité de l'ADN a été effectué sur tous les élues d'ADN en utilisant des méthodes d'électrophorèse sur gel fluorométrique, spectrophotométrique et d'agarose.

Résultats: Sur les 210 échantillons de LCR analysés microbiologiquement, la réaction de Gram était positive dans 94 cas $(44,8 \%)$, mais seulement $17(8,1 \%)$ étaient positives en culture pour deux des trois principales causes bactériennes de la méningite. Cent quatre-vingt $(85,7 \%)$ échantillons avaient des concentrations d'ADN $\geq 0,005$ $\mathrm{ng} / \mu \mathrm{L}, 55(30,6 \%)$ d'entre eux avaient une pureté d'ADN $\left(\mathrm{A}_{260 /} \mathrm{A}_{280}\right) \geq 1,7,103(57,2 \%)$ avaient une valeur de pureté comprise entre 1,0 et $1,69,14(7,8 \%)$ avaient une valeur de 0,57 à 0,99 , et $8(4,4 \%)$ ont échoué l'évaluation de la pureté avec une valeur de 0,00 à $A_{260 /} A_{280}$.

Conclusion: L'essence de l'extraction d'ADNm est polyvalente. Une PCR multiplex peut être effectuée sur l'ADNm extrait pour interroger la présence d'agents pathogènes microbiens d'intérêt en utilisant des amorces et des sondes spécifiques (le cas échéant). Un ADNm de qualité provenant d'échantillons de LCR assurera des résultats de qPCR réussis pour une détection rapide et précise des bactéries pathogènes dans la méningite. Cela éliminera les défis associés aux méthodes de culture traditionnelles.

Mots clés: méningite, LCR, contrôle de la qualité de l'ADN, fluorométrie

\section{Introduction:}

The continuous yearly outbreak of acute meningitis over the years no doubt had left behind very sad memories, moments in the minds and life of individuals (sufferers), family members, friends, communities and nations alike especially in the Meningitis Belt of Africa. Meningitis has been reported as one of the deadliest diseases that has been plaguing West Africa for decades. The sub-Saharan Africa was been plagued by large epidemics of meningococcal meningitis for a century, leading to it being labelled the 'meningitis belt' (1), spanning 26 countries (Fig 1 ).

Epidemics usually occur in the dry season which commences from December to June, with an epidemic wave that can last two to three years but dies out during the inter- vening raining seasons (2). In 1998, the World Health Organization attributed several factors to be associated with the development of epidemics in the Africa's meningitis belt. These factors include medical conditions (immunological susceptibility of the population), demographic conditions (travel and large population displacements), socioeconomic conditions (overcrowding, poor hygiene and living conditions), climatic conditions (drought and dust storms), and concurrent acute respiratory infections (3).

In Nigeria, about 5000 cases of meningitis occur every year with loss of many lives (4). The Nigeria Centre for Disease Control (NCDC) and Federal Ministry of Health (FMoH) Weekly Epidemiological Report from 2012 to 2018 revealed that this problem persists. Suspected cerebrospinal meningitis (CSM) cases within these seven years were 21,353 ; of which only 


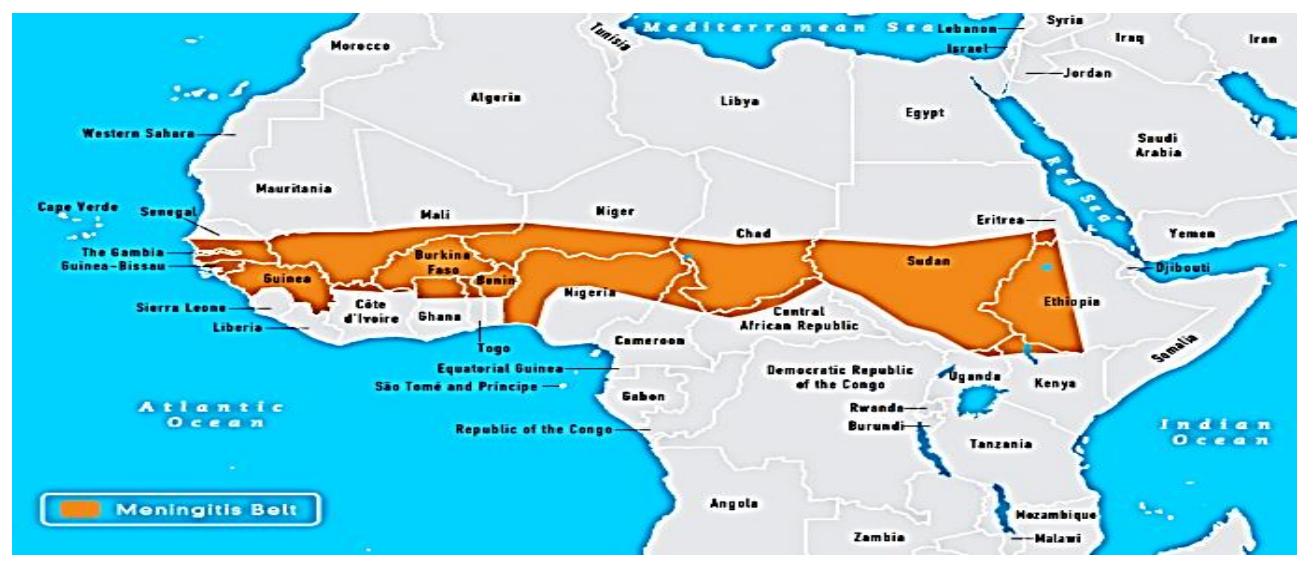

Fig 1: African Meningitis Belt

Source: African meningitis Belt/CDC. http://wwwn.cdc.gov/travel/yellowbook/2010/chapter-2/meningococcal-disease.aspx

643 cases $(3.01 \%)$ were laboratory confirmed. The number of deaths (case fatality ratio, CFR) was $1,347(6.31 \%)(5)$.

Bacterial meningitis remains a serious global health problem as well as a life-threatening condition that requires prompt recognition and treatment. It is also documented that, over 1.2 million cases of bacterial meningitis are estimated to occur worldwide each year (3). Without treatment, the case-fatality rates vary from $10 \%$ to greater than $50 \%(6)$, and can be as high as $70 \%$, with one in five $(20 \%)$ survivors left with permanent sequelae including hearing loss, neurologic disability, or loss of a limb (7).

The diagnosis of bacterial meningitis rests heavily on examination of CSF collected through lumber puncture (8). The presumptive identification of Neisseria meningitidis, Streptococcus pneumoniae and Haemophilus influenzae as well as other bacteria can be made on the basis of cytological examination of the CSF, specific colony morphology on blood and/or chocolate agar, staining properties on Gram stain or by detection of specific antigens in the CSF by latex agglutination test or a rapid diagnostic test (9). Although culture technique has been recommended as the 'gold standard' test because cultured bacteria are sources of data for antibiotic susceptibility, complete sub-typing, expression of antigens that are to be included in future vaccines, and understanding the pathophysiology of isolates, specimens that do not yield any culture growth can still be analyzed by molecular methods using metagenomic DNA (mDNA) extracted from clinical samples (9). A further probing into this statement by the CDC (9), revealed that they were actually referring to "metagenomic protocol" (either consciously or otherwise) aimed at tackling the 'yielded no growth syndrome' or abysmal low yield of CSF culture results. Culture was referred to as the 'gold standard' before now because it was the only method that provided evidence for the presence of any aetiological agent which can be used for further down-stream activities. In low income resource countries that do not have molecular diagnostic methods such as PCR, CSF culture method remains the best option.

Metagenomics is being described as the direct study of genetic materials recovered or extracted from microbial communities present in environmental samples, which take advantage of the rich diversity of genes and biochemical reactions of millions of non-cultivated and uncharacterized microorganisms (10). Metagenomics has been in the practice of microbiology for a while. Far away in 1935, Henrici and Johnson reported the known age long standard methods in bacteriology of "pure culture isolation and observation upon artificial media which often yield only an incomplete knowledge of a particular microbial flora" (11). Truly, microbial cultures have always been used to determine the microbial composition, but at the present, reports state that a large proportion of microorganisms in each ecosystem cannot be cultured with traditional tools, and their detection is only possible with DNA sequencing of their genetic fingerprints, the so-called metagenome (12). However, it should be clear at this point that the detection of bacteria in clinical or environmental samples by way of metagenomic approach is not only possible with DNA sequencing, but with molecular detection using multiplex PCR protocol with specific primers and probes (when applicable). Reports on estimates have it that cultured microorganisms account for less than $20 \%$ of the real phylogenetic diversity of pro- 
karyotes (13). Bacteria may be recalcitrant to culturing for diverse reasons such as lack of necessary symbionts, nutrients, or surfaces; excess inhibitory compounds; incorrect combinations of temperature, pressure, or atmospheric gas composition; accumulation of toxic waste products from their own metabolism; and intrinsically slow growth rate or rapid dispersion from colonies (14).

Due to the increase in the practice of starting antimicrobial therapy prior to clinical sample collection (15-18), the confirmation of aetiological agents of bacterial meningitis has been reported to decrease by about 30\% (16, 17). The use of molecular diagnostic protocol (especially PCR analysis) offers the advantages of detecting the DNA of serogroup-specific $N$. meningitidis as well as other implicating microorganisms, and not requiring live organisms for a positive result (19). In 2012, Foxman reported that advanced molecular techniques have provided the opportunity to detect trace amounts of genetic materials of a pathogen in various specimens with sensitivity that is far beyond culturebased methods (20).

Molecular techniques especially PCRbased assay, have become available to provide an early and accurate diagnosis of bacterial meningitis (21). This assay can detect as few as 10-100 CFU/mL of bacteria in CSF (22). PCR can be performed directly on clinical samples; the viability or otherwise of any organism present does not affect the result, this being that DNA can be extracted from clinical samples (typically blood and CSF) (9). The use of molecular assays for detection of aetiological agents of meningitis directly from CSF is now an established protocol.

The efficient extraction/preparation of DNA template is a necessary step for any realtime PCR (9) to meet the required DNA quality in terms of concentration, purity and quantity. The goal of DNA extraction is to lyze the bacterial cells in the specimens to maximize bacterial DNA yield and quality while removing any PCR inhibitors (i.e. salts, proteins), and dissolve the DNA in a buffer compatible with the enzymes used in the next analytical step while concentrating the extracted DNA at the same time (9). Commercial DNA extraction kits are available for culture, blood and body fluids (CSF inclusive). One of such DNA extraction kit is the Qiagen QIAamp ${ }^{(R)}$ DNA Mini Kit which provides fast and easy method for purification of total genomic DNA for reliable PCR, and can purify total DNA (e.g. metagenomic) from whole blood, plasma, serum, buffy coat, bone marrow, CSF, lymphocytes, cultured cells, tissue, and forensic specimens (23). The Qiagen QIAamp DNA Mini kit is a spin column technology in which DNA is selec- tively absorbed onto silica membrane (24). DNA purified using QIAamp kits is up to $50 \mathrm{~kb}$ in size, with fragments of approximately $20-30 \mathrm{~kb}$ predominating. DNA of this length denatures completely during thermal cycling and can be amplified with high efficiency.

It is mandatory to determine the quality (concentration and purity) of extracted metagenomic DNA before use for PCR assays. DNA yield can be assessed using various methods including absorbance (optical density), agarose gel electrophoresis, or fluorescent DNA-binding dyes. The Eppendorf BioPhotometer Plus instrument used for quality check measures optical density (absorbance values) at 230, 260 and 280 nanometres and converts optical densities to concentrations. Dependent on the method, the results can be calculated through fixed factors, standards, or curve calibration. In addition to the results, the device also displays the absorbance values and some other important details, such as the common absorbance quotients e.g. $A_{260} / A_{280}$ and $A_{230} / A_{280}$ ratio for nucleic acid calculations. Purity is determined by calculating the ratio of absorbance at $260 \mathrm{~nm}$ to absorbance at $280 \mathrm{~nm}$. Pure DNA (good quality DNA) has $A_{260} / A_{280}$ ratio of $1.7-1.9$, although reading lower than 1.6 does not render the DNA unsuitable for any application, but lower ratios may indicate the presence of more contaminants (25). Elution buffer for genomic DNA is usually $1 \times$ Tris EDTA buffer at $\mathrm{pH}$ 8.0.

For checking DNA quality and yield, RNase/DNase free water (nuclease free water) is used to dilute samples and to zero the spectrophotometer while the absorbance is measured at $A_{260}$ and $A_{280} \mathrm{~nm}$. Both DNA and RNA are measured with spectrophotometer, however, to measure only DNA, a fluorometer must be used (23). Quality check of DNA extract by agarose gel electrophoresis is one of the most frequently used techniques in life sciences (26). DNA fragments loaded on agarose gels would have been stained with ethidium bromide and detected by an ultraviolet (UV) transilluminator system (27). Agarose gel electrophoresis is also another way to quickly estimate DNA concentration.

Fluorescence measurement of nucleic acids is based on the use of fluorogenic dyes that bind selectively to DNA or RNA. Dyes only emit signal when bound to the target, and signal is measured by fluorometers. Sample is excited with filtered light (at the excitation wavelength), and the emitted light (at the emission wavelength) is recorded by a detector (28). The objective of this study is to evaluate the quality of mDNA (concentration, purity, and amount) extracted by spin column technique (Qiagen 
QIAamp) from CSF samples and control strains using fluorometric, spectrophotometric and gel electrophoresis methods.

\section{Materials and method:}

\section{Study settings}

The study sites were in Federal Capital Territory (FCT): National Hospital, Abuja; all District/General Hospitals in the FCT (Asokoro, Wuse, Maitama, Garki, Gwarinpa, Bwari, Kubwa, Kuje, and Nyanya), and some States in Northern Nigeria. However, CSF samples were not received from any District/General Hospital in the FCT; but from National Hospital, Abuja and also from Kebbi, Plateau, Sokoto and Zamfara States in Northern Nigeria during outbreak seasons of February - May 2017 and January April, 2018.

\section{Ethical consideration}

Ethical approvals were obtained from the Ethics Committees of National Hospital, Abuja (NHA/EC/034/2015), Federal Capital Development Authority Health Services (FHREC/ 2017/01/27/03-04-17), Kebbi State Ministry of Health (MOH/KSREC/VOL.1/56/No 101.3/2015), Plateau State Ministry of Health (MOH/MIS/ 202/VOL.T/X,2017), Sokoto State Ministry of Health (SMH/1580/V.IV, 2017), and Zamfara State Ministry of Health (ZSHREC/02/03/2017).

A letter of introduction from the Nigeria Centre for Disease Control (NCDC) of the Federal Ministry of Health (Ref. MH/2768/S.162/III) was obtained to cover for all outbreak sites in the country. Written informed consent for storage and future use of unused samples, sample materials and data transfer agreement, were also obtained.

\section{Subjects}

All hospitalized patients (all ages and gender) with clinical symptoms of meningitis as reviewed by the attending physicians were included in the study. Patients who did not give informed consent and sites that did not grant approval were excluded from the study.

\section{Sample size and sampling method}

The sample size was determined using the Cochran formula (29) for calculating simple proportion; $n_{0}=z^{2} p q / e^{2}$, where ' $n_{0}$ ' is the minimum required sample size, ' $z$ ' is the selected critical value of desired confidence level at 95\% (standard value of 1.96), ' $p$ ' is the estimated proportion of an attribute that is present in the population [estimated prevalence of meningitis in Zamfara State of $13.7 \%$ (30)], ' $q$ ' is $1-p$ and ' $e$ ' is the desired level of precision (margin of error at $5 \%$; standard value of 0.05$)$. Therefore, the estimated sample size was 181.7 which was adjusted to 210 samples after calculating for $10 \%$ attrition. The subjects were recruited consecutively until the sample size was attained.

\section{Collection and transportation of CSF specimens}

CSF was collected into sterile containers

by experienced physicians after performing lumbar puncture under aseptic conditions. The samples were transported to the laboratory at the various sites and kept at $-20^{\circ} \mathrm{C}$ before being transported in ice-packs to Abuja for onward transfer to the Safety Molecular Pathology Laboratory, Enugu, where the samples were kept at $-80^{\circ} \mathrm{C}$ until mDNA extraction was carried out.

\section{Metagenomic DNA extraction}

The Qiagen QIAamp ${ }^{(R)}$ DNA Mini kit was used for mDNA extraction of the CSF samples, bacterial isolates and three ATCC control strains (N. meningitidis serogroup B ATCC $13090, \mathrm{H}$. influenzae Type B, Biotype 1 ATCC 10211, and S. pneumoniae serotype 19F ATCC 49619). Approximately $200 \mu \mathrm{L}$ each of the CSF, bacterial isolates from the CSF (kept in 10\% Skim milk with $15 \%$ glycerol) and ATCC bacterial control strains in TE buffer, were transferred into $2.0 \mathrm{~mL}$ microcentrifuge (Eppendorf) tubes. $20 \mu \mathrm{L}$ of proteinase $\mathrm{K}$ was added to all samples, vortexed at $2000 \mathrm{rpm}$ for 5 seconds, and incubated at $56^{\circ} \mathrm{C}$ for 15 minutes. $60 \mu \mathrm{L}$ buffer $\mathrm{AL}$ was added, mixed thoroughly by vortexing for 15 seconds, incubated at $70^{\circ} \mathrm{C}$ for 10 minutes and briefly centrifuged to remove drops from the lid of the tube. $200 \mu \mathrm{L}$ ethanol (96-100\%) was added, vortexed for 15 seconds and briefly centrifuged to remove drops from the lid of the tube.

The mixture was pipetted onto the QIAamp Mini spin column (in a $2 \mathrm{ml}$ collection tube), centrifuged at 6000xg (8000rpm) for 1 min, and the flow-through and collection tube discarded. The QIAamp Mini spin columns were placed in a new $2 \mathrm{ml}$ collection tube, 500 $\mathrm{L}$ buffer AW1 was added, centrifuged at $6000 \times \mathrm{xg}$ (8000rpm) for $1 \mathrm{~min}$ and the flow-through and collection tube discarded. The QIAamp Mini spin columns were placed in a new $2 \mathrm{ml}$ collection tube, $500 \mu \mathrm{L}$ buffer AW2 was added, centrifuged at full speed of $20,000 \times \mathrm{g}(14,000 \mathrm{rpm})$ for 3 min and the flow-through and collection tube discarded. The QIAamp Mini spin columns were then placed in a new $1.5 \mathrm{ml}$ collection tube and $60 \mu \mathrm{L}$ buffer $\mathrm{AE}$ added, incubated at room temperature for $1 \mathrm{~min}$ and centrifuged at 6000xg (8000rpm) for $1 \mathrm{~min}$ to elute the mDNA. Eluted DNA samples were labelled accordingly for quality check and appropriately stored for later use. 


\section{Metagenomic DNA extract quality check}

The quality of the extracted mDNA was performed by the fluorometric method (for concentration) and spectrophotometric method (for purity). The agarose gel electrophoresis method was used to access few DNA samples for the presence or absence of bands only. Fluorescence method for DNA concentration

The Qubit 3.0 fluorometer instrument (Invitrogen Life Technologies, now ThermoFisher) was used to determine the concentration of the extracted mDNA from the samples. Assay components were equilibrated at room temperature; the Qubit ${ }^{(R)}$ working solution was prepared by diluting Quant - iT ${ }^{\mathrm{TM}}$ dsDNA HS reagent $1: 200$ in Quant - iT ${ }^{\mathrm{TM}}$ dsDNA HS buffer. $200 \mu \mathrm{L}$ of working solution was prepared for each standard and sample. The assay tubes were prepared according to Table 1 .

All tubes were vortexed for 2-3 sec. The tubes were incubated for 2 minutes at room temperature. The tubes were inserted in the Qubit 3.0 fluorometer and readings taken. The Qubit 3.0 fluorometer was calibrated using the readings of the Standard Assay Tubes ( 8 in number) with concentrations range of $0.0 \mathrm{ng} / \mu \mathrm{l}$ to $10.0 \mathrm{ng} / \mu \mathrm{l}$, and prepared a standard curve to determine DNA amounts in user samples (unknown DNA sample concentrations). For the calibration curve, data from Qubit 3.0 were entered into GraphPad Prism and linear regression of DNA standards was determined (Table 2) and used in reading the relative fluorescence unit of samples (Table 3 ).

Table 1: Protocol for preparing assay tubes for fluorometric method

\begin{tabular}{ccc}
\hline Volume of solution/analyte & Standard Assay Tubes & $\begin{array}{c}\text { Unknown DNA (user) } \\
\text { samples Assay Tubes }\end{array}$ \\
\hline Volume of working solution (from step 2) to add & $190 \mu \mathrm{l}$ & $195 \mu \mathrm{l}$ \\
Volume of standard (from kit) to add & $10 \mu \mathrm{l}$ & $5 \mu \mathrm{l}$ \\
$\quad$ Volume of user sample to add & - & $200 \mu \mathrm{l}$
\end{tabular}

Thin-walled, clear 0.5ml PCR tubes were used. Acceptable tubes include Qubit ${ }^{(R)}$ assay tubes (set of 500 - Cat No. Q32856) or Axygen PCR - 05 - C tubes (VWR, Part No. $10011-830$ ). The minimum assay volume must be $200 \mu$ l.

Table 2: Characteristics of the Linear Regression for DNA check by Fluorometric Method (Qubit 3.0)

\begin{tabular}{ll}
\hline Best-fit values & Relative Fluorescent Unit (RFU) \\
\hline Slope & $1651 \pm 53.21$ \\
Y-intercept when $X=0.0$ & $487.1 \pm 268.9$ \\
X-intercept when $Y=0.0$ & -0.2950 \\
1/slope & 0.0006056 \\
$95 \%$ Confidence Intervals & 1503 to 1799 \\
Slope & -259.4 to 1234 \\
Y-intercept when $X=0.0$ & -0.8004 to 0.1478 \\
X-intercept when $Y=0.0$ & \\
Goodness of Fit & 0.9959 \\
R square & 464.5 \\
Sy.X & \\
Is slope significantly non-zero? & 962.9 \\
F & $1.000,4.000$ \\
DFn, DFd & $<0.0001$ \\
P value & Significant \\
Deviation from zero? & \\
Data & 6 \\
Number of X values & 1 \\
Maximum number of $Y$ replicates & 6 \\
Total number of values & 0 \\
Number of missing values & \\
\hline
\end{tabular}


Table 3: Fluorometric readings of standards

\begin{tabular}{ccc}
\hline & Concentration $(\mathrm{ng} / \mu \mathrm{l})$ & RFU value \\
Std1 & 10.00 & 17203.03 \\
Std2 & 8.00 & 9922.97 \\
Std3 & 6.00 & 9735.85 \\
Std4 & 4.00 & 7538.76 \\
Std5 & 1.00 & 2423.75 \\
Std6 & 0.50 & 989.15 \\
Std7 & 0.00 & 532.96 \\
\hline
\end{tabular}

Table 4: Spectrophotometer Method - Operation

\begin{tabular}{cccc}
\hline Method group & Method & Description & Wavelength \\
\hline DNA & dsDNA & $\begin{array}{c}\text { Calculating the concentration of DNA } \\
\text { with evaluation via factor. Already pre- } \\
\text { programmed factor ex-factory }\end{array}$ & $\begin{array}{c}\text { Measuring wavelength: 260nm } \\
\text { Secondary wavelength to check for } \\
\text { purity: } 280 \mathrm{~nm}\end{array}$ \\
\hline
\end{tabular}

Copyright $^{(R)} 2007$ Eppendorf AG, Hamburg, Germany

\section{Spectrophotometric method for DNA purity}

In the spectrophotometric method, the Eppendorf BioPhotometer Plus instrument was used to determine the purity of the extracted metagenomic DNA from the samples. Measuring procedure was according to literature insert in the manufacturer's manual, with the instrument set for dsDNA and sample dilutions of $5 \mu \mathrm{L}$ sample $+95 \mu \mathrm{L}$ diluent for reading at $A_{260} / A_{280}$. The Eppendorf BioPhotometer Plus instrument switched-on to initialize. Sample preparation ( $95 \mu \mathrm{L}$ of diluent distilled water) was pipetted into appropriately labelled tubes. $5 \mu \mathrm{L}$ of mDNA extract was added to the corresponding labelled tubes. The sample was transferred into a clean cuvette shaft of outside diameter $12.5 \mathrm{~mm} \mathrm{x}$ $12.5 \mathrm{~mm}$. The instrument was set at blank (zero) before reading at $A_{260} / A_{280}$ wavelength (Table 4). Result was recorded for purity value at $A_{260} / A_{280}$ and dsDNA concentration in $\mu \mathrm{g} / \mathrm{mL}$ but readings of the dsDNA concentration were disregarded because of inconsistent values (non-reproducibility of readings).

\section{Gel electrophoresis method}

In the gel electrophoresis method, the Biorad Horizontal Gel Electrophoresis tank was used in running of some samples. The set gel (1.5\% agarose) was well placed into the tank and filled to the brim with $0.5 x$ Tris Borex EDTA (TBE). $5 \mu \mathrm{L}$ of mDNA extract was pipetted into microtitre plate wells appropriately. $3 \mu \mathrm{L}$ of loading dye (10 x Dream Taq Green Buffer which includes $20 \mathrm{mM} \mathrm{MgCl}_{2}$ ) was added into all samples in the microliter plate wells and well mixed. The loading dye helps the DNA extract (sample) to sink into the well of the gel. Each gel well was loaded with the sample and covered with adequate $0.5 \times T B E$. The electrophoresis tank is connected to the power pack with positive and negative terminals, and switched on. The gel was run at 100 volts for 45-60 min. The gel was then transferred to the UV transilluminator that is fitted with a camera system which is viewed on a computer connected to the camera system. Using the GenoSpot programme and EOS Utility (for the Camera) that are installed on the computer, snap shot gel pictures of the mDNA bands were taken, saved and labelled appropriately.

\section{Calculating amount of mDNA extracts}

The mDNA concentration $(n g / \mu L)$ was measured by the Qubit Fluorometer $3.0 \mathrm{~g}$. The DNA yield = DNA concentration $x$ eluted volume $(60 \mu \mathrm{L})$ per $200 \mu \mathrm{L}$ of $\mathrm{CSF}$. The amount of DNA = DNA concentration $\times 5 \mu \mathrm{L}$ per qPCR reaction.

\section{Results:}

Of the 210 subjects recruited into the study, 129 (61.4\%) were males, comprising $104(49.5 \%)$ children ( $<15$ years of age) and 25 (12\%) adults while females were 81 (38.6\%), comprising 66 ( $31.4 \%)$ children ( $<15$ years) and 15 (7.1\%) adults (Table 5). Following microbiological analysis, Gram reaction was positive in $94(44.8 \%)$ samples while only $17(8.1 \%)$ were culture positive for two of the three bacteria under study (Table 6).

Table 7 shows the summary of results obtained from linear regression for mDNA concentration by fluorometric method (Qubit 3.0) on the 210 CSF samples. Metagenomic DNA was extracted from $180(85.7 \%)$ samples with concentrations of $\geq 0.005 \mathrm{ng} / \mu$ l [relative fluorescent unit (RFU) value of 537.32] being the lowest limit of detection (LOD), while 30 $(14.3 \%)$ had DNA concentration less than 0.005 
$\mathrm{ng} / \mu \mathrm{l}$. The amounts of mDNA present in the 180 $(85.7 \%)$ samples were DNA concentration of $0.03-50.5 \mathrm{ng} / \mu \mathrm{l}$, DNA yield of $1.8-3030 \mu \mathrm{g}$ and
DNA amount of $0.15-252.5 \mathrm{ng} / \mu \mathrm{l}$. Table 8 is the summary results of mDNA purity values at $A_{260 /} A_{280}$ and concentration of $\geq 0.005 \mathrm{ng} / \mu \mathrm{l}$.

Table 5: Age group and gender distribution of subjects recruited for the study

\begin{tabular}{cccc}
\hline Age group (years) & Male (\%) & Female (\%) & Total (\%) \\
\hline$<15$ & $104(49.5)$ & $66(31.4)$ & $170(81.0)$ \\
$>15$ & $25(11.9)$ & $15(7.1)$ & $40(19.0)$ \\
Total & $129(61.4)$ & $81(38.6)$ & $210(100)$ \\
\hline
\end{tabular}

Table 6: Results of Gram reaction, culture and metagenomic DNA on the CSF samples

\begin{tabular}{ccc}
\hline Test & \multicolumn{2}{c}{ CSF samples } \\
\cline { 2 - 3 } Gram reaction & Number positive & Percentage \\
Culture & 94 & 44.8 \\
Metagenomic DNA $(\geq 0.005 \mathrm{ng} / \mathrm{ul})$ & 17 & 8.1 \\
\hline CSF = cerebrospinal fluid & 180 & 85.7 \\
\hline
\end{tabular}

Table 7: Linear regression for mDNA concentration by fluorometric method (Qubit 3.0) on CSF samples

\begin{tabular}{cccc}
\hline Concentration (ng/ul) & RFU value & No of samples & Percentage \\
\hline $0.005-\geq 10.00$ & $537.32-\geq 17203.03$ & 180 & 85.7 \\
$0.00-<0.005$ & $532.96-<537.32$ & 30 & 14.3 \\
Total & & 210 & 100 \\
\hline
\end{tabular}

$\overline{R F U}=$ Relative Fluorescent Unit; mDNA = metagenomic DNA

Table 8: Spectrophotometric results of mDNA purity at $A_{260 / A} A_{280}$ and concentration of $\geq 0.005 \mathrm{ng} / \mu \mathrm{L}$

\begin{tabular}{ccc}
\hline Purity @ A260/A280 & Number of samples & Percentage \\
\hline$\geq 1.7$ & 55 & 30.6 \\
$1.0-1.69$ & 103 & 57.2 \\
$0.57-0.99$ & 14 & 7.8 \\
0.00 & 8 & 4.4 \\
Total & 180 & 100 \\
\hline
\end{tabular}


Fig 2 shows the linear regression plot for mDNA concentration. Fig 3 shows gel picture of ATCC bacterial control strains that had DNA purity at $A_{260 /} A_{280}$ of 1.53 (N. meningitidis), 1.48
(H. influenzae), and 1.57 (S. pneumoniae) and Fig 4 shows the gel electrophoresis picture of mDNA of samples that had purity range of 1.04.37 at $A_{260 /} A_{280}$.

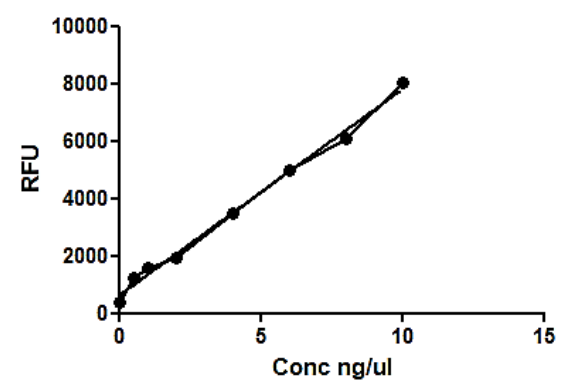

Fig 2: Linear Regression Plot for DNA Concentration

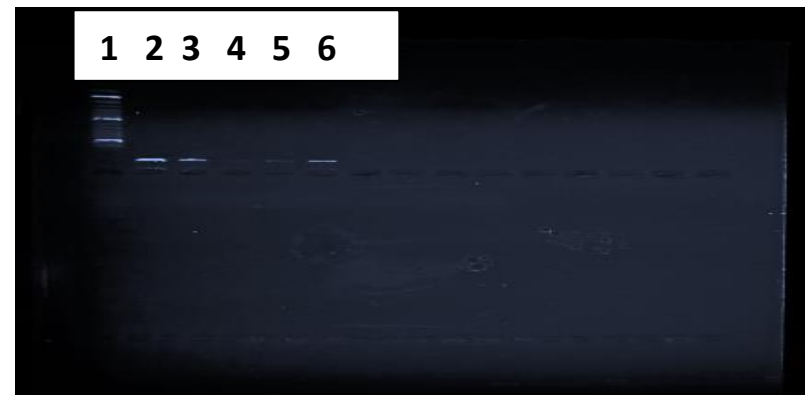

Lane 1 - DNA ladder; Lane 2 - N. meningitidis (DNA purity @ $\mathrm{A}_{260} / \mathrm{A}_{280}-1.53$ ); Lane 3 - H. influenzae (DNA purity @ A $260 / \mathrm{A}_{280}-$ 1.48); Lane 4 - S. pneumoniae (DNA purity @ $\left.A_{260} / A_{280}-1.57\right)$; Lane 5 - N. meningitidis (DNA purity @ $A_{260} / A_{280}-1.53$ ); Lane 6 H. influenzae (DNA purity @ $\left.A_{260} / A_{280}-1.48\right)$

Fig 3: Gel electrophoresis picture of ATCC bacterial control strains

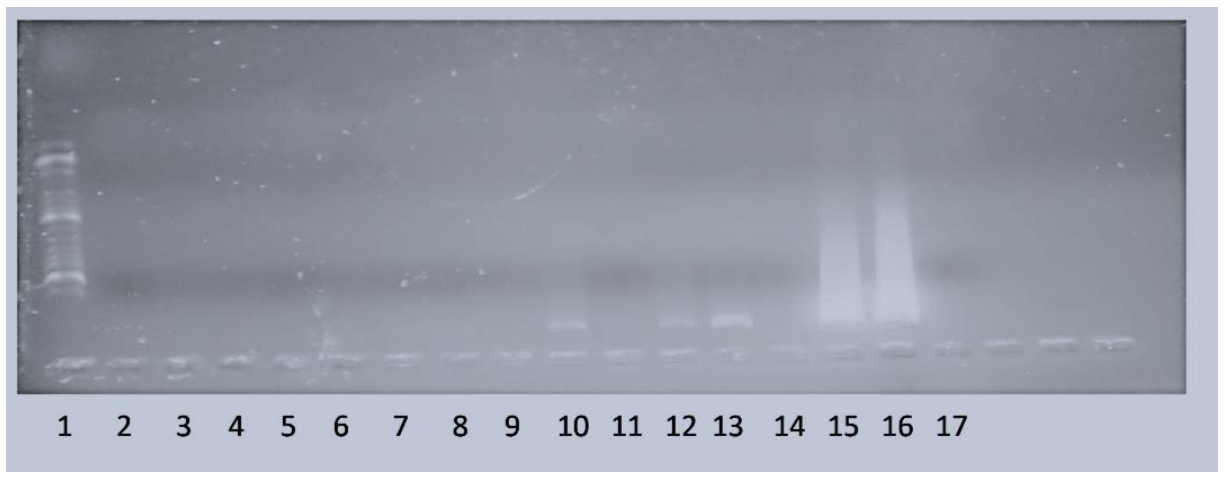

Lane 1: DNA Ladder (50 bp); Lane 2: IP01N (DNA purity @ A260/A280 - 1.23; DNA Conc. $1.3 \mathrm{ng} / \mu \mathrm{L})$; Lane 3: IP07N (DNA purity @

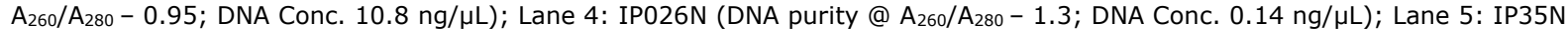
(DNA purity @ $A_{260} / A_{280}-3.1$; DNA Conc. $0.04 \mathrm{ng} / \mu \mathrm{L}$ ); Lane 6: IP62N (DNA purity @ $\mathrm{A}_{260} / \mathrm{A}_{280}-1.9 ;$ DNA Conc. $2.3 \mathrm{ng} / \mu \mathrm{L}$ ); Lane 7 IP95S (DNA purity @ $A_{260} / A_{280}-1.0 ;$ DNA Conc. $\left.5.9 \mathrm{ng} / \mu \mathrm{L}\right)$; Lane 8: IP101N (DNA purity @ $\mathrm{A}_{260} / \mathrm{A}_{280}-1.2 ; \mathrm{DNA}$ Conc. $\left.1.2 \mathrm{ng} / \mu \mathrm{L}\right) ;$ Lane 9: IP128H (DNA purity @ $A_{260} / A_{280}-1.1 ; D N A$ Conc. $\left.0.97 \mathrm{ng} / \mu \mathrm{L}\right) ;$ Lane 10: IP147N (DNA purity @ $\mathrm{A}_{260} / \mathrm{A}_{280}-1.2 ;$ DNA Conc. $5.8 \mathrm{ng} / \mu \mathrm{L})$; Lane 11: IP157H (DNA purity @ $\mathrm{A}_{260} / \mathrm{A}_{280}-8.1$; DNA Conc. $6.1 \mathrm{ng} / \mu \mathrm{L}$ ); Lane 12: IP178S (DNA purity @ $\mathrm{A}_{260} / \mathrm{A}_{280}-1.4$; DNA Conc. $1.8 \mathrm{ng} / \mu \mathrm{L}$ ); Lane 13: IP189N (DNA purity @ A $260 / \mathrm{A}_{280}-1.8$; DNA Conc. $4.7 \mathrm{ng} / \mu \mathrm{L}$ ); Lane 14: IP209N (DNA purity @ $\mathrm{A}_{260} / \mathrm{A}_{280}$ - 2.0; DNA Conc. $\left.1.1 \mathrm{ng} / \mu \mathrm{L}\right) ;$ Lane 15: Nm ATCC (DNA purity @ $\mathrm{A}_{260} / \mathrm{A}_{280}-1.5 ;$ DNA Conc. $\left.15.1 \mathrm{ng} / \mu \mathrm{L}\right) ;$ Lane $16: \mathrm{Hi}$ ATCC (DNA purity @ A $\mathrm{A}_{260} / \mathrm{A}_{280}$ - 1.48; DNA Conc. $\left.20.0 \mathrm{ng} / \mu \mathrm{L}\right)$ ); Lane 17: Sp ATCC (DNA purity @ $\mathrm{A}_{260} / \mathrm{A}_{280}$ - 1.6; DNA Conc. $16.6 \mathrm{ng} / \mu \mathrm{L}$ )

Fig 4: Gel electrophoresis picture of mDNA samples (DNA purity @ $A_{260 / 280}$ of $1.10-4.37$ ) 


\section{Discussion:}

The findings of our study showed that Gram reaction was positive in $44.8 \%(94 / 210)$ of CSF samples of the patients and culture in $8.1 \%$ $(17 / 210)$ while $85.7 \%(180 / 210)$ yielded mDNA concentrations of $\geq 0.005 \mathrm{ng} / \mathrm{ml}$. Of the 180 samples, spectrophotometric reading for DNA purity value of $\geq 1.7-12.20$ (good quality DNA) was recorded in $55(30.6 \%), 1.0-1.69$ (quality DNA) in 103 (57.2\%), 0.57-0.99 (low quality DNA) in $14(7.8 \%)$ with only 8 samples $(4.4 \%)$ failing purity evaluation (with value of 0.00 at $\mathrm{A}_{260 / 280}$ ). In a recent metagenomic study by Zhang et al., (32) on 135 patients, 26 (19.3\%) were culture positive while $32(23.7 \%)$ were identified by metagenomic next generation sequencing (mNGS). This is the closest method to the one we used. While their method was mNGS, ours is still at the level of mDNA extraction from CSF samples and subsequent molecular identification and characterization by qPCR of the three bacteria of interest ( $N$. meningitidis, $H$. influenzae, and $S$. pneumoniae). Our study therefore provides a strong baseline data for processing CSF samples for qPCR without the need for culture, and shows that majority of samples would yield quality DNA material ( $>1.0$ $\mathrm{ng} / \mu \mathrm{L})$.

The gel electrophoresis results showed spatial bands, that could be linked to the percentage of agarose in the gel used (1.5\%), which is good in resolving linear DNA molecules size range of $300-3000 \mathrm{bp}$ (31) as against the amplicon size of the bacteria of interest; $N$. meningitidis (127 bp), $H$. influenzae (113 bp), and $S$. pneumoniae (51 bp). The strength of our research lies on the fact that metagenomic protocol does not rely on bacterial culture and isolation for extraction of mDNA for use in the detection of aetiological agents of meningitis, but rather on the constituent DNA concentration present in the sample. However, one limitation to our study is that we did not include viral pathogens, being that RNA was not extracted. Another limitation is that we did not perform restriction digest of the extracted mDNA or PCR amplification of $16 \mathrm{~S}$ rDNA on the extract, which would have confirmed the suitability of the extracted mDNA for downstream processing.

\section{Conclusion:}

Quality mDNA from CSF samples will ensure successful qPCR results for rapid and accurate detection of bacterial pathogens in meningitis, beginning first at molecular detection using multiplex real-time PCR (rt-PCR) down to species-specific singleplex rt-PCR. This will eliminate the time and labour consuming traditional culture methods often associated with "yielded no growth syndrome" or abysmal low yield of CSF culture output resulting in the very poor outcome of laboratory confirmed cases of cerebrospinal meningitis (CSM).

\section{Acknowledgements:}

The authors acknowledge the Federal Ministry of Health, Nigeria and the ethics committee members of National Hospital, Abuja, Nigeria; Kebbi State Ministry of Health, Nigeria; Plateau State Ministry of Health, Nigeria; Sokoto State Ministry of Health, Nigeria; and Zamfara State Ministry of Health. All staff of the various laboratories where the samples were received and phenotypically processed are appreciated. Special thanks to Prof. Chikaike Ogbonna, Department of Community Medicine, Faculty of Clinical Sciences, University of Jos, Nigeria for his assistance and to Prof. Tatfeng Mirabeau, Department of Medical Laboratory Science, College of Health Sciences, Niger Delta University, Amassoma, Wilberforce Island, Bayelsa State, Nigeria.

\section{Authors contributions:}

PIC and IEI conceived, and led the design and writing of the manuscript. PIC, NUP, UYB, DLD, OCN, and MR processed the CSF samples at the various sites for phenotypic methods, storage, and transportation of the samples to Abuja and finally to Safety Molecular Pathology Laboratory, Enugu for storage at $-80^{\circ}$ C. NE and NCR were responsible for molecular biology techniques (PCR) orientation, training and processing of CSF samples extraction and quality check of DNA. PIC fully participated in performance of the PCR activities. PIC, IEI, and NE were responsible for the final editing of the manuscript.

\section{References:}

1. Lapeyssonnie, L. Cerebrospinal meningitis in Africa.

Bull World Health Organisation. 1963; 28: 1-114.

2. Greenwood, B. Manson Lecture. Meningococcal meningitis in Africa. Trans R Soc Trop Med Hyg. 1999; 93 (4): 341-353

3. World Health Organization. Control of epidemic meningococcal disease, practical guidelines, $2^{\text {nd }}$ edition, WHO/EMC/BA/98. 1998; 3: 1-83.

4, Nnadozie, C. Nigeria records 5000 cases of Cerebrospinal meningitis annually. Daily Independent Newspaper, Nov 3, 2013.

5. Nigeria Centre for Disease Control (NCDC). Weekly Epidemiological Reports (2012 - 2018) https://ncdc.gov.ng

6. Nigeria Centre for Disease Control (NCDC). Meningitis. 2019; 14: 09:11. https://ncdc.gov.ng/diseases/factsheet/49

7. Rosenstein, N. E., Perkins, B. A., Stephen, D. S., et al. Meningococcal Disease. N Engl J Med. 2001; 
344: 1378-1388.

8. Bonadio, W. A. The cerebrospinal fluid: physiologic aspects and alterations associated with bacterial meningitis. Paediatr Infect Dis J. 1992; 11: 423432.

9. Centers for Disease Control and Prevention (CDC). PCR for detection and characterization of Bacterial meningitis pathogens: Neisseria meningitidis, Haemophilus influenzae, and Streptococcus pneumoniae. In: Laboratory Methods for the Diagnosis of Meningitis, Chapter 10. Second edition. 2011. http://www.cdc.gov/meningitis/lab-manual/ index.html

10. Blamey, J. M., Fischer, F., Meyer, H., et al. Enzymatic Biocatalysis in Chemical Transformations: A Promising and Emerging Field in Green Chemistry Practice. In: Brahmachari, G (ed). Biotechnology of Microbial Enzymes. Production, Biocatalysis and Industrial Applications. Elsevier Inc., Academic Press, 2017; 347 - 403

11. Henrici, A. T., and Johnson, D. E. Studies of Freshwater Bacteria. II. Stalked Bacteria, a New Order of Schizomycetes. J Bacteriol. 1935; 30 (1): 61-93.

12. Yarza, P., Yilmaz, P., Pruesse, E., et al. Uniting the Classification of Cultured and Uncultured Bacteria and Archaea using 16S rRNA Gene Sequences. Nat Rev Microbiol. 2014; 12 (9): 635-645.

13. Wu, D., Hugenholtz, P., Mavromatis, K., et al. A Phylogeny - Driven Genomic Encyclopaedia of Bacteria and Archaea. Nature. 2009; 462 (7276): 1056-1060.

14. Simu, K., and Hagstrom, A. Oligotrophic Bacterioplankton with a Novel Single-Cell Life Strategy. Appl Environ Microbiol. 2004; 70 (4): 2445-2451.

15. Boving, M. K., Pedersen, L. N., and Moller, J. K. Eight-plex PCR and liquid-array detection of bacterial and viral pathogens in Cerebrospinal fluid from patients with suspected meningitis. J Clin Microbiol. 2009; 47: 908-913.

16. Corless, C. E., Guiver, M., Borrow, R., et al. Simultaneous detection of Neisseria meningitidis, Haemophilus influenzae, and Streptococcus pneumoniae in suspected cases of meningitis and septicaemia using real-time PCR. J Clin Microbiol. 2001; 39: 1553-1558.

17. Ghotaslou, R., Frajnia, S., Yeganeh, F., et al. Detection of Acute Childhood Meningitis by PCR, Culture and Agglutination Tests in Tabriz, Iran. Acta Medica Iranica. 2012; 50: 192-196.

18. Shin, S. Y., Kwon, K. C., Park, J. W., at al. Evaluation of the Seeplex ${ }^{(R)}$ Meningitis ACE Detection Kit for the Detection of 12 Common Bacterial and Viral Pathogens of Acute Meningitis. Ann Lab Med. 2012; 32 (1): 44-49.
19. Richardson, D. C., Louie, L., Louie, M., et al. Evaluation of a rapid PCR assay for diagnosis of meningococcal meningitis. J Clin Microbiol. 2003; 41: 3851-3853.

20. Foxman, B. Molecular Tools and Infectious Disease Epidemiology. Burlington, MA: Elsevier; 2012.

21. Schuurman, T., de Boer, R. F., Kooistra-Smid, A. M., et al. Perspective Study of the use of PCR amplification and sequencing of $16 \mathrm{~S}$ ribosomal DNA from cerebrospinal fluid for diagnosis of bacterial meningitis in a clinical setting. J Clin Microbiol. 2004; 42: 734 - 740.

22. Kennedy, W. A., Chang, S. J., Purdy, K., et al. Incidence of bacterial meningitis in Asia using enhanced CSF testing: polymerase chain reaction, latex agglutination and culture. Epidemiol Infect. 2007; 135 (7): 1217-1226.

23. QIAamp ${ }^{(R)}$ DNA Mini and Blood Mini Handbook. Fifth Edition, 2016. HB-0329-004(C) 1999-2016 QIAGEN. www.qiagen.com

24. QIAamp ${ }^{(R)}$ DNA Mini Kit Quick-Start Protocol, 2018. www. qiagen.com

25. Promega. How do I determine the concentration, yield and purity of a DNA sample? 2019. www.promega.com

26. Lee, P. Y., Costumbrado, J., Hsu, C. Y., et al. Agarose gel electrophoresis for the separation of DNA fragments. JoVE. 2012; 20 62): 3923.

27. Aaij, C., and Borst, P. The Gel Electrophoresis of DNA. Biochimica Biophysica Acta. 1972; 269 (2): 192-200.

28. Thermo Fisher Scientific. Life Technologies User Guide, Qubit ${ }^{(R)} 3.0$ Fluorometer Catalog Number Q33216, Publication Number MAN0010866; Revision A. O. 2014.

29. Cochran, W. G. (ed). Calculation of Sample Size when Population is Infinite. In: Sampling Techniques. Third Edition. John Wiley \& Sons, Inc. New York, 1977.

30. Mado, S. M., Abubakar, U., Onazi, S. O., et al. Epidemic Cerebrospinal meningitis in Children at Federal Medical Centre, Gasau, Zamfara State. Niger J Paediatr. 2013; 40 (2): 169-171.

31. Barril, P., and Nates, S. Introduction to Agarose and Polyacrylamide Gel Electrophoresis Matrices with Respect to Their Detection Sensitivities. In: Magdeldin, S. (ed). Gel Electrophoresis - Principles and Basics. InTech. Janeza Trdine 9, 51000 Rijeka Croatia, 2012.

32. Zhang, X., Guo, L., Liu, L., et al. The diagnostic value of metagenomics next-generation sequencing for identifying Streptococcus pneumoniae in paediatric bacterial meningitis. BMC Infect Dis. 2019; 19: 495 